Egypt. Poult. Sci. Vol. (41) (III): (525-534) (2021)

http://www.epsj.journals.ekb.eg/

ISSN: 1110-5623 (Print) - 2090-0570 (Online)

\title{
COMPARISON OF PHYLOGENIC TREE AND GENE SEQUENCE OF SALMONELLA ENTERITIDIS ISOLATED FROM DIFFERENT BIRDS
}

\author{
Ghada, O. El-demerdash ${ }^{1}$, Amr, E. M. Mahmoud ${ }^{2}$, Nahed yahia ${ }^{3}$ \\ And Heba. Roshdy ${ }^{3}$ \\ 1- Anim.Health Res. Inst., Fayoum bran., Agric. Res. Center, Egypt \\ 2-Bio. Dep., Fayoum Uni., Egypt. \\ 3- *Ref. Lab. for Vet. Quality Control on Poult. Prod., Anim. Health Res. Instit., Minis.try of \\ Agric., Nadi El-Seid Street, Dokki P.O. Box246, Giza 12618, Egypt
}

Corresponding Author: Heba. Roshdy3 E-mail: roshdy2019 @ yahoo.com

\begin{abstract}
Salmonella is bacterium causing high morbidity and mortality rates in the birds'. The present study was performed on a total of 100 samples from diseased and apparently healthy quail came from governorates (Giza, Cairo, Damietta and kafrelsheik). Collected samples included different organs (liver, heart, lung, and bone marrow). And a comparison between the genetic tree and gene sequences of Salmonella isolated from \{chicken-ducks and rabbit $\}$. The bacteriological examination revealed that out of 100 collected samples, 22 samples (22\%) were positive for Salmonella isolation. the serotyping of Salmonella species isolates showed a major variety of serotypes which included Salmonella Enteritidis (27.3\%); Salmonella Typhimurium and Salmonella Senftenberg (22.8\% for- each ); Salmonella Agona, (18.1\%) and Salmonella Magherafelt (9\%) . Results of the sensitivity testing of salmonella isolated from quail. Showed that $(72.8 \%, 68.2 \%)$ of strains were resistant to Nalidixic acid and Streptomycin, but sensitive to Gentamicin, Trimethoprim-sulfamethoxazole, $(68.2 \%)$ of strains. Also, all Salmonella isolates showed multidrug resistance. We selected three strains to be sequenced with accession number MT267777 to MT267779 and it resembled Salmonella enterica subsp. enterica serovar Enteritidis strain from China, Korea, and UK with $100 \%$ identitiy percent.
\end{abstract}

Key words: Salmonella enteritides, antibiotic sensitivity, sequence gene. 
Ghada, O. El-demerdash et al

\section{INTRODUCTION}

One of the main important pathogen is salmonella as it is food born disease that causes severe economic losses and down grade food product Centers for Disease Control, (2015)

Salmonella is bacteria of Gram- negative, facultatively anaerobic, usually motile it is one from the family Entero bacteriaceae Douglas et al., (2015). Salmonella present in the alimentary tract but not one of the normal flora of poultry if it was infected. It causes decrease villi number, irritation of the intestinal wall that lead to lower absorption Pelicano et al., ( 2005) also it secretes toxins like ammonia or amines, which affect the hosts liver. isit present in poultry and some of its species has zoonotic effect like (Salmonella enterica) so humane could infected through ingestion of contaminated food especially poultry product Saba et al., (2013).

Poultry plays an important role in the transmission of Salmonella to human as there are several serovars were isolated from poultry and human EFSA, (2019).

Quail birds are small migratory birds so it faces many parasites, infectious, and noninfectious diseases, and as it is a bird it takes the same diseases as poultry especially salmonella and may cause zoonotic diseases Yee et al., (2009), Ngulukun et al., (2010).

Biochemical and serological tests are the most used commonly used methods for detection and identification of Salmonella spp. But methods are delay in diagnosis, treatment and control of infections. Ranjbar et al., (2013). Salmonellosis is still a major food borne disease in human and the significance of Salmonella species as causes of human and animal disease has increased in the recent years. Saba et al., (2013).
Antibiotic resistance is widespread and resistance has been elevated by world health organizations as one of the top health challenges. The escalating cases of antibiotic resistance have raised concerns that we are entering a "post antibiotic era" meaning we might enter an era where there won't be effective antibiotics to treat many life threatening infections Douglas et al., (2015).

Various virulence genes are important for Salmonella pathogenesis, such genes are placed on different genome elements as plasmids, chromosome, Salmonella genomic islands (SGIs), and integrated bacteriophage DNA and Salmonella pathogenicity islands (SPIs) (Card et al., (2016), Riyaz-Ul-Hassan et al., (2004); and Jamshidi et al., (2010) . The stn gene is in attendance in all Salmonella serotypes and contained a unique sequence that considered as suitable PCR target for detection of Salmonella strains in field samples Ammar et al., (2019).

So, it is work aims to isolate and identity attempting to isolate the salmonella microbe from quail with its characterization, which helps in ease and speed of diagnosis and studying the resistance pattern of isolates to antibiotics used in quail. And a comparison between the genetic tree and gene sequences of Salmonella isolated from different birds.

MATERIALS AND METHODS

Collected Samples: A total of 100 samples from diseased and healthy quail came from governorates (Giza, 30-Cairo, 20-Damietta, 20- and Kafrelsheikh, 30). Collected samples included different organs (liver, heart, lung, and bone marrow). The samples were collected under aseptic conditions and safety precautions to prevent- cross contamination according to Middleton et al., (2005). A comparison between the 
Salmonella enteritides, antibiotic sensitivity, sequence gene.

genetic tree and gene sequences of Salmonella isolated from \{chicken-ducks and rabbit\}.

Isolation and Identification of Salmonella according to ISO 6579-1: 2017. Briefly, Samples were weighed and suspended in buffered peptone water (as 1:10 dilution) then incubated at $37^{\circ} \mathrm{C} \pm 1^{\circ} \mathrm{C}$ for $16-20$ hours aerobically. The pre- enrichment broth after incubation was mixed and 0.1 $\mathrm{ml}$ of the broth was transferred into a tube containing $10 \mathrm{ml}$ of RappaportVassiliadis medium with soya (RVS broth). Another $1 \mathrm{ml}$ of the pre enrichment broth was transferred into a tube containing $10 \mathrm{ml}$ of MullerKauffmann tetra thionate novobiocin broth (MKTTn broth). The inoculated RVS broth was incubated at $41.5{ }^{\circ} \mathrm{C} \pm 1{ }^{\circ} \mathrm{C}$ for $24 \pm 3$ hours and the inoculated MKTTn broth at $37^{\circ} \mathrm{C} \pm 1^{\circ} \mathrm{C}$ for $24 \pm 3$ hours. Then a loop-full of material from the RVS broth and MKTTn was transferred and streaked separately onto the surface of Xylose Lysine Deoxycholate Agar (XLD agar), Hektoen Enteric (HE agar) and MacConkey's Agar separately. The plates were incubated in an inverted position at $37^{\circ} \mathrm{C} \pm 1^{\circ} \mathrm{C}$ for $24 \pm$ 3hours aerobically then checked for growth of typical Salmonella colonies .The typical and selected colonies were identified by biochemical tests (Urea agar, Triple sugar iron, and Lysine iron).

Serotyping of isolated Salmonella species according to ISO 6579-3: 2014 and reading of Salmonella species by

Kauffman - White scheme Grimont and Weill, (2007) using Salmonella antiserum (Sifin Co., Japan®).

\section{antiobiotic sensitivity test:}

The antibiogram of isolates was done by disc diffusion test according to Koneman et al., (1997) against 10 antibiotic discs purchased from Oxoid (Amoxicillin
+Clavulanic acid, Chloramphenicol, Ciprofloxacin, Gentamicin, Nalidixic acid, Nitrofurantoin, Norfloxacin, Streptomycin, Trimethoprimsulfamethoxazole and Tetracycline). The interpretation according to the Clinical and Laboratory Standards Institute/ Formerly National Committee for Clinical Laboratory Standard according to CLSI/NCCLS, (2017).

\section{dna amplification and sequencing:}

The (22) positive samples for isolation were confirmed by PCR. The DNA was extracted from samples using a QIAmp viral DNA mini kit (Qiagen, Hilden, Germany), according to the manufacturer's instructions. The salmonella enteritidis genes were amplified using gene- specific primers and Phusion ${ }^{\circledR}$ high fidelity DNA polymerase (Thermo Fisher Scientific, MA, USA), according to the manufacturers protocol. We selected represented samples from positive flocks from different governorates to be sequenced. Purification was carried out using the QIAquick Gel Extraction Kit (Qiagen, Hilden, Germany). Sequencing was performed using a BigDye Terminator v3.1 Cycle Sequencing Kit (Applied Biosystems, California, USA) with gene-specific primers, and the nucleotide sequence was obtained from an ABI 3500 Genetic Analyzer (Life Technologies, California, USA).

\section{RESULTS AND DISCUSSIONS}

Poultry can become infected with different Salmonella serotypes with high morbidity and mortality during the first three weeks of their life, and may also become carriers bacteria spread horizontally or vertically leading to embryo mortality or rapid death of newly hatched birds. The prevalence of Salmonella infection in Chinese poultry 


\section{Ghada, O. El-demerdash et al}

farms has been widely described Yang, et al., (2019). Salmonella enteric serovar Typhimurium and S. enterica serovar Enteritidis are the most frequently encountered species from foods like poultry, pork and beef products Vose, et al., (2013).

In the present study, 100 quail samples (included 50 from life disease and 50 from freshly dead one) were collected from (Giza, Cairo, Damietta and kafrelsheik governorates) were examined bacteriologically for the presence of Salmonella. Postmortem examination of the dead quails showed septicemia, fibroins pericarditis, perihepatitis, peritonitis, airsaculitis and some cases showed abs cessation of the viscera. The bacteriological examination revealed that 22 out of 100 collected samples, (22\%) were positive for Salmonella isolation (Table2, 3). The obtained results were in contrast to those recorded by Dipineto et al., (2014) in which no Salmonella was isolated from quail flocks examined. Similar results were obtained by Palanisamy and Bamaiyi (2015).

(Table, 4.) Salmonella enter-itidis was recovered only from dead bird's liver, heart and bone marrow and likely associated with systemic infection . S. Enteritidis contaminated eggs leading to public health concerns. The diseased birds may show lesions of pericarditis, per hepatitis and septicaemia. Islam et al., (2016).

In this study, the serotyping of Salmonella species isolates showed a major variety of serotypes which included Salmonella Enteritidis (27.3\%); Salmonella Typhimurium and Salmonella Senftenberg (22.8\% for each ), Salmonella Agona, (18.1\%) and Salmonella Magherafelt (9\%) (Table, 5). Harsha et al., (2011) and Bacci et al.,
(2012) recorded that the most frequently isolated serotypes in the quail samples $\mathrm{S}$. Enteritidis (17.1\%). Also $S$. Enteritidis, $S$. Typhimurium, $S$. Sinstorf and $S$.Vejle were isolated from chicks while, $S$. Enteritidis, $S$. Muenster and $S$. Cuckmere were isolated from turkey poults. Similarly, Jodas and Hafez (2002). Isolated different types of Salmonella spp. identified S. enterica subspecies Enterica; S. Corvalis, S. Give, S. Lexington, S. Minnesota, S. Schwarzengrund, S. Rissen, and S. Typhimurium from meconium samples. Freitas et al., (2013) and Udhayavel et al., (2016).

(Table, 6). The excessive and massive usage of antibiotics on in-tensive food especially poultry represent the cornerstone for the emer-gence, persistence and spread of the resistant bacteria repre-sent a major threat to human health globally WHO, (2014). The resistance bacteria in food animals can transmit to humans directly contact with the animal or indirectly from environment that receives these bacteria from infected animals and fecal materials FAO, (2011) and WHO, (2011). The sensitivity testing of salmonella isolated from quail. Showed that $(72.8 \%$, $68.2 \%$ ) of strains were resistant to Nalidixic acid and Streptomycin, but sensitive to Gentamicin and Trimethoprim-sulfamethoxazole, (68.2\%) of strains. Also, all Salmonella isolates showed multidrug resistance. In a study by Jahan et al., (2018). The lowest percentage was $20 \%$ to Nalidixic acid, Rahman, et al., (2011).

Reported that in vitro amplification of DNA by PCR method is a powerful tool in microbiological diagnostics and, showed that the PCR-based assays were more sensitive than the culture method 
Salmonella enteritides, antibiotic sensitivity, sequence gene.

for detection of Salmonella. In addition to that obtained by Freitas et al., (2010) who concluded that the mPCR was able to detect the presence of these bacteria in a short period and enabled the identification of serotype Enteritidis in one of the samples found positive for Salmonella species. Moreover, Akiba et al., (2011). We make PCR amplification of Hypthetical protein of salmonella Entraitidis and the result was positive for 22 samples from 100 at $304 \mathrm{pb}$.

We selected three strains to be sequenced with accession number MT267777 to MT267779 and it was resemble to Salmonella enterica subsp. enterica serovar Enteritidis strain from china, korea, Uk with $100 \%$ identitiy percent. This result has resembled to Akiba et al., (2011).

\section{CONCLUSION}

Salmonella enteritis is counted as one of the major bacteria causing severe problems in poultry farms. So, to minimize the economic losses in the poultry production firm hygienic measures should be applied. Further investigations should continue to characterize the antibiotic resistance genes and the epidemiology link between poultry and human. Biosecurity on the poultry farms should be the first line of defense against infectious diseases.

Table (1): Sequences of primer and the size of amplified products.

\begin{tabular}{|l|l|l|l|l|}
\hline $\begin{array}{l}\text { Bacterial } \\
\text { strains }\end{array}$ & Target gene & The Sequence of the primers 5'-3' & $\begin{array}{l}\text { PCR } \\
\text { Size } \\
\text { (bp) }\end{array}$ & refrence \\
\hline S. Enteritidis & $\begin{array}{c}\text { SEN1383 } \\
\text { hypothetical } \\
\text { protein }\end{array}$ & $\begin{array}{c}\text { F:TGTGTTTTATCTGATGCAAGAGG' } \\
\text { R:-TGAACTACGTTCGTTCTTCTGG' }\end{array}$ & 304 & $\begin{array}{c}\text { Ranjbar, } \\
\text { et al , } \\
2014\end{array}$ \\
\hline
\end{tabular}

Table (2): Incidence of salmonella recovered from examined quail samples in different governorates

\begin{tabular}{|c|c|c|}
\hline \multirow{2}{*}{ Locality } & \multicolumn{2}{|c|}{ Salmonella recovered from examined quail } \\
\cline { 2 - 3 } & No examined & No. positive \% \\
\hline Cairo & 30 & $6(20 \%)$ \\
Giza & 20 & $3(15 \%)$ \\
Damietta & 20 & $5(25 \%)$ \\
Kafrelsheik & 30 & $8(26 \%)$ \\
Total & 100 & $22(22 \%)$ \\
\hline
\end{tabular}

*Percentage according to total number of the examined samples in each governorates. 
Table (3): Numbers and Percent of the positive and negative examined samples.

\begin{tabular}{|c|c|c|c|c|c|}
\hline Birds status & $\begin{array}{c}\text { No. of } \\
\text { samples }\end{array}$ & $\begin{array}{c}\text { positive } \\
\text { number }\end{array}$ & $\begin{array}{c}\text { positive } \\
\text { \% }\end{array}$ & $\begin{array}{c}\text { Negative } \\
\text { number }\end{array}$ & $\begin{array}{c}\text { Negative } \\
\%\end{array}$ \\
\hline Scarified birds & 50 & 5 & 10 & 45 & 90 \\
Freshly dead & 50 & 17 & 34 & 33 & 66 \\
total & 100 & 22 & 22 & 78 & 78 \\
\hline
\end{tabular}

*Percentage according to total number of the examined samples.

Table (4): Incidence of Salmonella in different organs of quails.

\begin{tabular}{|l|c|c|c|c|c|c|c|c|c|}
\hline Bird & \multirow{2}{*}{$\begin{array}{c}\text { No. } \\
\text { status }\end{array}$} & \multicolumn{7}{|c|}{ Organ examined } \\
\cline { 3 - 9 } & $\begin{array}{l}\text { Examine } \\
\text { d of } \\
\text { positive }\end{array}$ & Liver & \%* & lung & \%* & Heart & \%* & $\begin{array}{l}\text { Bone } \\
\text { marrow }\end{array}$ & \%* \\
\hline $\begin{array}{c}\text { Scarified } \\
\text { birds }\end{array}$ & 5 & 2 & 40 & 0 & 0 & 1 & 20 & 2 & 40 \\
$\begin{array}{c}\text { Freshly } \\
\text { dead } \\
\text { Total }\end{array}$ & 17 & 8 & 47 & 2 & 11.7 & 2 & 11.7 & 5 & 29.6 \\
\hline
\end{tabular}

*Percentage according to total number of the examined samples.

Table (5): Serotyping results of Salmonella species isolated from quails.

\begin{tabular}{|l|c|c|}
\hline \multicolumn{1}{|c|}{ Serotype } & No. of isolates & \% \\
\hline Salmonella Enteritidis & 6 & 27.3 \\
Salmonella Typhimurium & 5 & 22.8 \\
Salmonella Senftenberg & 5 & 22.8 \\
Salmonella Agona & 4 & 18.1 \\
Salmonella Magherafelt & 2 & 9 \\
Total & 22 & 100 \\
\hline
\end{tabular}

*Percentage according to total number of the examined samples. 
Salmonella enteritides, antibiotic sensitivity, sequence gene.

Table (6): Results of antimicrobial sensitivity of salmonella isolates recovered from examined quail (total number of samples $=22$ )

\begin{tabular}{|c|c|c|c|c|c|c|}
\hline \multirow{2}{*}{$\begin{array}{c}\text { antimicrobial } \\
\text { agents }\end{array}$} & \multicolumn{2}{|c|}{ Resistance } & \multicolumn{2}{c|}{ Intermediate } & \multicolumn{2}{c|}{ Sensitive } \\
\cline { 2 - 7 } & No & \%* & No & \%* & No & \% \\
\hline Amoxicillin + & 5 & 22.7 & 15 & 68.2 & 2 & 9.1 \\
Clavulinic acid & & & & & & \\
Chloramphenico & 12 & 54.6 & 5 & 22.7 & 5 & 22.7 \\
Ciprofloxacin & 6 & 27.2 & 4 & 18.2 & 12 & 54.6 \\
Gentamicin & 3 & 13.6 & 4 & 18.2 & 15 & 68.2 \\
Nalidixic acid & 16 & 72.8 & 3 & 13.6 & 3 & 13.6 \\
Nitrofurantoin & 9 & 40.9 & 10 & 45.5 & 3 & 13.6 \\
Norfloxacin & 8 & 36.4 & 5 & 22.7 & 9 & 40.9 \\
Streptomycin & 15 & 68.2 & 4 & 18.2 & 3 & 13.6 \\
Trimethoprim- & 5 & 22.7 & 2 & 9.1 & 15 & 68.2 \\
sulfamethoxazole & & & & & & \\
Tetracycline & 5 & 22.7 & 9 & 40.9 & 8 & 36.4 \\
\hline
\end{tabular}

*Percentage calculated according to total number of the examined samples.

\section{REFERENCES}

Akiba, M. Kusumoto, M. and Shilwata, T. 2011. Rapid identification of Salmonella enterica serovars, Typhimurium, Choleraesuis, Infantis, Hadar, Enteritidis, Dublin and Gallinarum, by multiplex PCR. Journal of Microbiological Methods, 85(1): 9-15.

Ammar, A. M.; Abdeen, E. E.; Abo Shama, U. H.; Fekry, E. and Kotb Elmahallawy, E.2019. molecular characterization of virulence and antibiotic resistance genes among Salmonella serovars isolated from broilers in Egypt. Lett. Appl. Microbiol.; 68 (2): 188 - 195. Cortez, A. L.; Carvalho, A. C.; Ikuno,

Bacci, C. Boni, E. Alpigiani, I.; Lanzoni, E.; Bonardi, S. and Brindani, F. 2012. Phenotypic and genotypic features of antibiotic resistance in Salmonella enterica isolated from chicken meat and quail carcasses. Int. J. Food Microbiol, 160(1): 16-23.

Card, R. Vaughan, $K$ and Bagnall, $M$. 2016. Virulence characterization of Salmonella enterica isolates of diering antimicrobial resistance recovered from UK livestock and imported meat samples. Front Microbial 7: 640.

Centers for Disease Control. 2015. Surveillance for foodborne disease outbreaks United States, 2015: annual report [cited 2018 Feb 5].Atlanta; 2015. Available from: https://www.cdc.gov/foodsafety/pdfs/2 015FoodBorneOutbreaks_508.pdf/.

Clinical and Laboratory Standards Institute (CLSI) 2017. Performance standards for antimicrobial susceptibility testing. 27th Informational Supplement Document M100- S27, CLSI, Wayne, Vol. 37: (1).

Dipineto, L.; Russo, T.P.; Gargiulo, A.; Borrelli, L.; De Luca Bossa, L.M.; 
Santaniello, A.; Buonocore, P.; Menna, L.F. and Fioretti, A. 2014. Prevalence of enteropathogenic bacteria in common quail (Coturnix coturnix). Avian Pathol. 43:498- 500.

Douglas, E.C, Nelson, A.C. Mark, A.H, Wilson, L.J, Buhr, and FedorkCray, P.J. 2015. Salmonella and antimicrobial resistance in broilers. Journal of Applied Poultry Research. 24: (3) 408-426.

EFSA.2019. The European Union One Health 2018 Zoonoses Report European Food Safety Authority and European Centre for Disease Prevention and Control (EFSA and ECDC).

FAO, 2011. Antibiotics in farm animal produc-tion: Public health and animal welfare.

http://www.fao.org/fileadmin/user_upl oad/animalwel-

fare/antibiotics_in_animal_farming.pd f.

Freitas, C.G.; Santana, A.P. and Silva, H.C. 2010. PCR multiplex for detection of Salm -onella Enteritidis, Typhi and Typhimurium and occurrence in poultry meat. International Journal of Food Microbiology. 139 (1-2): 15-22.

Freitas, N. O. C, Angela, H.L, Soares, N.M, Guastalli ,E.A.L, Almeida, A.M, and Berchieri ,J. A. 2013. Salmonella spp. in meat-type quails (Coturnix coturnix coturnix) in the State of São Paulo, Brazil. Brazilian Journal of Poultry Science, 15 (3): 169-286.

Grimont, P.A.D and Weill, F.X. 2007. Antigenic formulas of the Salmonella Serovars. $9^{\text {th }}$ ed. WHO Collaborating Center for reference and research on Salmonella. Paris.
Harsha, H.T, Reshmi, R, Rinoy, V, Divya, P.S. Mujeeb, R.K. and Mohamed, H. A. 2011. Prevalence and antibiotic resistance of Salmonella from the eggs of commercial samples. Journal of Microbiology and Infectious Disease, 1 (3): 93-100.

International organization for standardization ISO 6579 part 1 2017. Microbiology of the food chain -Horizontal method for the detection, enumeration and serotyping of Salmonella -Part 1: Detection of Salmonella spp. International Standards Organization. Geneva.

International organization for standardization ISO 6579 part 3 2014. Microbiology of food and animal feeding stuffs -Horizontal method for the detection of Salmonella. International Standards Organization. Geneva.

Islam,m.d. T, Talukder, A.K, Rahman, M. d A, Haider, M. d G, Abu Nasar, M. d and Aminoor, R. 2016. Incidence of diseases in Japanese quail (Coturnix coturnix japonica) with special reference to bacterial and viral diseases in some selected areas of Bangladesh. Asian Australian Journal of Bioscience and Biotechnology, 1 (3): 410-418.

Jahan, S, Zihadi, M, N. NHKHM, Islam SMd, Rahman BMd and Rahman M 2018. Molecular detection and antibiogram of Salmonella spp. from apparently healthy Japanese quails of three different quail farms in Mymensingh. Journal of Advanced Veterinary Animal Research, 5 (1): 60- 66.

Jamshidi, A., Kalidari, G.A., Hedayati, M. 2010. Isolation and identification of Salmonella enteritidis and Salmonella typhimurium from the 
Salmonella enteritides, antibiotic sensitivity, sequence gene.

eggs of retail stores in Mashhad, Iran using conventional culture method and multiplex PCR assay. J. Food. Safety. 30: $558-568$

Jodas S and Hafez, H.M 2002. Field investigations on the efficacy of inactivated Salmonella Enteritidis vaccine (Salenvac ${ }^{\circledR}$ ) in turkey breeder flocks. Proceedings of the 4th International Symposium on Turkey Diseases. Ed Hafez HM. Berlin, Germany, 259-270.

Koneman, E.W., Allen S.D., Janda W.M., Schreckenberger P.C. and Winn W.C. 1997. Diagnostic. Microbiology. 5th ed.Chapter 1. Philadelphia. Newyork.

Middleton, J.R. Fales, W.H., Luby, C.D., Landsay, Oaks, J.; Susan Sanchez, Kinyon, J.M.; Wu, C.C.; Maddox, C.W. and Hartmann, F. 2005. Surveillance of Staphylococcus aureus in veterinary teaching hospitals. J Clin Microbiol 43(6): 2916-2919.

Ngulukun, S.S., Oboegbulem, S.I., Fagbamila, I.O., Emennaa, P.E., Ankeli, P.I., Ardzard, S.S., Okeke, L.A., Ajayi, O.T., Usman, M., Muhammed, M.J., Odugbo, M.O. and Okewole, P.A.2010.Isolation of thermophilic Campylobacter species from Japanese quail (Coturnixcoturnix) in Vom, Nigeria. The VeterinaryRecord, 166, $147-148$.

Palanisamy, S. and Bamaiyi, P.H. (2015): Isolation and Antibiogram of Salmonella spp. from Quails in a Farm from Kelantan, Malaysia. J Vet Adv 201 5, 5(1 2): 1191 - 1198.

Pelicano, E., P.A. Souza, H.B.A. Soza, D. F. Figueiredo, M.M. Boiago, S.R. Carvahlo, and Bordon,V.F. 2005. Intestinal mucosa development in broiler chickens fed growth promoters". Brazilian J. poultry Sci., 7(4):221 -229.

Rahman, M. M., Hossain, M. K., Akhter, M. R., Hasan, S. M. K., and Rahman, M. M. 2011. Characterization and antibiogram study of salmonella serovars isolated from duck, quail and pigeon in Dinajpur district of Bangladesh. International Journal of Sustainable Agricultural Technology 7(2):23-29.

Ranjbar, R. Naghoni, A. Yousefi, S. Ahmadi, A. Jonaidi, $\mathbf{N}$ and Panahi, Y. 2013. The Study of genetic relationship among third generation cephalosporin-resistant Salmonella enterica strains by ERIC-PCR. Open Microbiol J, 7: 142- 5.

Ranjbar R, Naghoni A, Farshad S, Lashini H, Najafi A, Sadeghifard N, Mammina C 2014. Use of TaqMan ${ }^{\circledR}$ real-time PCR for rapid detection of Salmonella enterica serovar Typhi. Acta Microbiol Immunol Hung, 61(2): 121-30. 14.

Riyaz-Ul-Hassan, S., Verma, V. and Qazi, G.N. 2004. Rapid detection of Salmonella by polymerase chain reaction. Mol. Cell. Probes. 18: 333339.

Saba, C.K., Escudero, J.A., HerreraLeon, S., Porrero, M.C., Suarez, M., Dominguez, L., Demuyakor, B. and GonzalezZorn, B. 2013. First identification of Salmonella Urbana and Salmonella Ouakam in humans in Africa. J. Infect. Dev. Ctries. 7 (10): $691-695$.

Udhayavel, S. Murthy, T.R. Gowthaman, V. Senthilvel, $K$ and Kumar, G. S. 2016. Isolation and identification of Salmonella enterica from Japanese quail in India. International Journal of Applied Research, 2 (12): 645-647. 
Ghada, O. El-demerdash et al

WHO, (World Health Organization)
2011. Critically important
antimicrobials
forhumanmedicine.Available.

WHO, (World Health Organization),

2014. An-timicrobial resistance: Global report on surveil-lance. Geneva, Switzerland.

Yang, J., Gao, S., Chang, Y., Su, M., Xie, Y., Sun, S. 2019. Occurrence and Characterization of Salmonella Isolated from Large-Scale Breeder Farms in Shandong Province, China. Biomed. Res. Int. 2019.
Yee, K.S., Cardona, C.J. and Carpenter, T.E. 2009. Transmission of low pathogenicity avian influenza virus of subtypeH6N2 from chickens to Pekin ducks and Japanese quail (Coturnix coturnix japonica).Avian Pathology, 38, 59-64.

Vose, D., T. Koupeev and K. Mintiens, 2013. A quantitative microbiological risk assessment of Salmonella spp. in broiler (Gallus gallus) meat production. EFSA Supporting Publ., Vol. 8. 10.

$$
\begin{aligned}
& \text { الملخص العربي } \\
& \text { مقارنة بين الثجرة الوراثية وتسلسل الجينات من السالمونيلا انترتيدس المعزولة من الطيور } \\
& \text { المختلفة }
\end{aligned}
$$

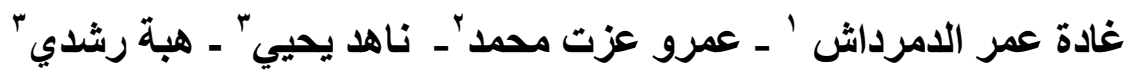

$$
\begin{aligned}
& \text { 1- معهد بحوث صحة الحيوان ، فرع الفيوم ، مركز البحوث الزراعية ، مصر } \\
& \text { r ـ كلية الطب البيطري قسم الكيماء،فرع الفيوم، مصر }
\end{aligned}
$$

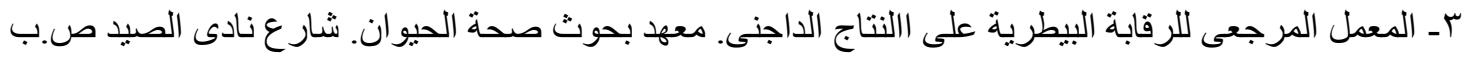

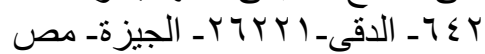

